asked me to make a cytological examination of the material.

Good preparations of flower buds were obtained by using Carnoy's fixative followed by the fixative of La Cour (NATURE, July 27, 1929, p. 127) and Newton's gentian violet method. In one of the sterile plants examined, a ring of four chromosomes was found to occur regularly at the heterotypic division of the pollen-mother-cells. The two pairs $\left(A A^{\prime}\right.$ and $\left.B B^{\prime}\right)$ can be distinguished with comparative ease. In Fig. I $(b)$ and $(c)$ indicates the alternative ways in

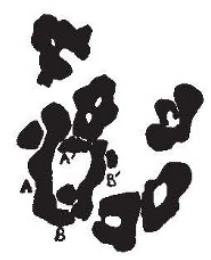

$a$

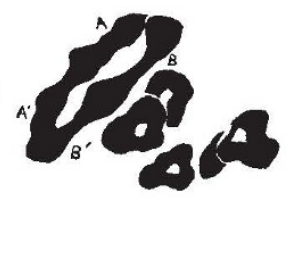

$b$

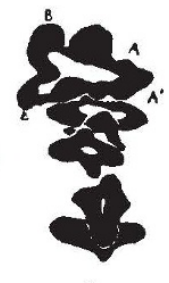

$c$
FIG. 1.-Camera lucida drawings of a chromosome ring in Pisum sativum. Magnification about 2500 diameters.

which chromosome separation may take place. It is suggested that the method illustrated in $(c)$, in which two homologous chromosomes (of the ring) go to each pole, will give rise to non-viable gametes, whereas that shown in $(b)$ will give rise to viable gametes. If the two methods of separation occur equally often, the ring formation may account for the 50 per cent sterility observed in many of the plants in this family.

I have examined several other strains of peas, and in all I have found the chromosomes arranged in seven pairs, as is characteristic of the species. Håkansson (Hereditas, 12, 1929) has, however, observed the formation of a ring of four chromosomes in the experimental material of Dr. Hammerlund, in which two factors, usually independent, were found to be linked.

John Innes Horticultural Institution,

Eva Richardson. London, S.W.19, Aug. 27.

\section{Planaria alpina in Lithuania.}

Planaria alpina has been considered as very limited in its distribution and has played an important part in the theoretical discussions of the preglacial and the postglacial fauna of Europe. It has been reported from England, from various parts of southern Europe, from Scandinavia (cí. A. Thienemann, "Planaria alpina auf Rügen und die Fiszeit", Jahresb. Geogr. Ges. Greifswald., 10; 1906), and recently from Finland (A. Luther). It appears that this animal, with the notable exception of Finland, has not been found east of the Baltic Sea. It has never been reported from Prussia, from the Baltic States, or from the adjacent parts of Russia. Dr. A. Luther considers that specimens found in Finland show a relationship with Scandinavia, that is, with the countries west of the Baltic rather than those of the east. I have found Planaria alpina, however, on the eastern coast of the Baltic as well.

While investigating the planarian fauna in the springs of Eiguliai, some four or five kilometres north of Kaunas, early last June, I found a single specimen which on close examination proved to be Planaria alpina. After repeated visits to the same place I was able to confirm my findings, and up to this time I have collected seven specimens. The animal is rather rare, and the specimens are quite small, none of them being longer than $9 \mathrm{~mm}$. when fully extended alive. Some of the specimens show recent fission, and none of them are sexually mature.

$P$. alpina in Lithuania is restricted to permanent springs where the annual changes of the water temperature are a minimum. Repeated attempts have been made to find them in a creek nearby, which is fed by the same springs, and so far not a single one has been found there.

My conclusion is that $P$. alpina is more widely distributed than it is generally supposed to be. I am sure that sooner or later it should be found in other Baltic States and in the western part of Russia, that is, in the region connecting Finland and Lithuania.

Universitetas, Kaunas, P. B. Srvickis. Lithuania.

\section{Cosmic Rays and Cancer.}

IN a letter appearing in NATURE of June 29, I suggested that change in the intensity of cosmic radiations might have influenced the incidence of malignant disease.

Millikan found that at high altitudes the effective intensity of these rays was many times as great as at sea-level. As a source of ionisation, these rays possess a power of penetration unequalled by any other known.

I suggest the desirability of direct experiments to ascertain whether at high altitudes appreciable effects would ensue in the progress of malignant disease or on its primary development. In such experimentswhich must of course be differential in charactersimilarity in the factors of temperature and atmospheric pressure at greatly differing altitudes would be easily attained without notable influence on the penetrating rays.

Consequences of grave practical importance might arise out of such experiments. At any rate they must throw some light on a very obscure and important subject.

Trinity College, Dublin, J. JoLY. June 27.

\section{Probable Origin of the Cold Wave in India, February 1929.}

DURING the period Jan. 28-Feb. 3, 1929, an intense cold wave overran the whole of the north-west and centre of India, where surface temperature went down to about $12^{\circ} \mathrm{C}$. below normal, several stations recording the lowest temperature in the last four or five decades. The results of a few soundings over Agra, which reached the stratosphere during and after the passage of the cold wave, appear to throw some light on the origin of the cold air. During winter the normal height of the tropopause over Agra (Lat. $27^{\circ}$ ) is about $14.5 \mathrm{gkm}$. and its temperature is $206^{\circ} \mathrm{A}$. (see Dr. Ramanathan's Fig. 1, Nature, June 1, p. 834), while with the invasion of the cold wave the base of the Agra stratosphere came down so low as $11.5 \mathrm{gkm}$. and its temperature rose to $213^{\circ} \mathrm{A}$. The conditions in the troposphere and the stratosphere over Agra during the cold wave were similar to those normally found at about Lat. $40^{\circ}$. The trajectories of pilot. balloon flights up to $6 \mathrm{~km}$. indicate that the cold air came from the north-west. It would thus appear that the cold wave had its origin somewhere to the east of the Caspian Sea.

S. C. Roy.

Meteorological Department, G. Chatterji. Poona. 